\title{
Cell death in the gastrulating chick embryo: potential roles for tumor necrosis factor-alpha (TNF- $\alpha$ )
}

\author{
Esmond J. Sanders ${ }^{2}$, Sita Prasad ${ }^{1}$, Ninghe $\mathrm{Hu}^{1}$ and \\ Michael A. Wride ${ }^{1}$ \\ 1 Department of Physiology, University of Alberta, Edmonton, Alberta, Canada, \\ T6G 2H7, Canada \\ 2 corresponding author: Department of Physiology, University of Alberta, \\ Edmonton, Alberta, Canada, T6G 2H7. tel: 403-492-5486; fax: 403-492-8915; \\ e-mail: esanders@physio.med.ualberta.ca
}

Received 31.5.96; revised 12.08.96; accepted 4.10.96 Edited by C.J.Thiele

\begin{abstract}
We have examined the expression of TNF- $\alpha$ and its receptors, TNFR1 and TNFR2, during gastrulation in the chick embryo, and have investigated the possible role of this factor in the control of cell death at this early stage of development. TNF- $\alpha$, immunoreactive at approximately $17 \mathrm{kD}$, was found both in vivo and in vitro, most intensely associated with the cell surface and cytoskeleton of endoderm cells. TNFR2 was especially immunoreactive in endoderm cells of the marginal zone. TNFR1 was found in nuclei throughout the embryo. Embryos also showed widespread expression of both the bcl2 and Bax gene products, which are both associated with cell death pathways. Intact embryos in culture were sensitive to the addition of TNF- $\alpha$ (approx. $110 \mathrm{ng} / \mathrm{ml}$ ), responding by significantly increasing the incidence of DNA fragmentation in cells from all tissues of the embryo. This effect was abrogated by immunological pre-absorption of the cytokine. Cultured cells from these embryos also responded to the addition of agonistic antibodies to TNF- $\alpha$ receptors by increasing DNA fragmentation. A similar response to TNF- $\alpha$ antiserum by cultured cells appeared to be related to a concomitant decrease in cell-substratum adhesion caused by the antibody. Decreased cell adhesion, induced non-specifically with antiintegrin antiserum, also resulted in increased DNA fragmentation. TNF- $\alpha$, synthesized and secreted by the embryo itself, may be able to exert a paracrine effect on the incidence of cell death in tissues of the embryo, and the cell death process may be related to the expression of bcl-2 and Bax gene products. The influence of TNF- $\alpha$ may be exerted by the activation of cell death signalling pathways directly, or indirectly through perturbation of the cytoskeleton or of integrin-mediated cell adhesion.
\end{abstract}

Keywords: chick, embryo, gastrulation, cell death, TNF- $\alpha$

Abbreviations: AEC, 3-amino-9-ethyl carbazole; BrdU, Bromodeoxyuridine; BSA, Bovine serum albumin; DDW, Double distilled water; ICE, Interleukin-1 $\beta$-converting en- zyme; IFN-gamma, Interferon-gamma; ITS, Insulin, Transferrin, Selenium; PBS, Phosphate buffered saline; SM, Skimmed milk; TNF- $\alpha$, Tumor necrosis factor- $\alpha$; TNFR1, Tumor necrosis factor receptor 1; TNFR2, Tumor necrosis factor receptor 2; TUNEL, terminal deoxynucleotide transferase-mediated dUTP-biotin nick-end-labelling; UTP, Uridine triphosphate

\section{Introduction}

It has been recognized for many years that cell death during embryonic development is a significant contributor to the process of morphogenesis (Glücksmann, 1951; Saunders, 1966; Snow, 1987; Sanders and Wride, 1995). Some welldefined sites where the importance of this cell death has been particularly widely acknowledged include: the limb bud (Hinchliffe, 1981); the heart (Pexieder, 1975); and the palate (Ferguson, 1988). However, it has also been noted that cell death is a feature of morphogenesis at much earlier stages of development, such as during gastrulation (Bellairs, 1961), neural tube closure (Schlüter, 1973), and neural crest formation (Jeffs et al, 1992; Homma et al, 1994). At these early times in development, the extent and patterns of cell death are very much less clear, and its significance is essentially unknown.

Data on cell death in the pre-streak mammalian embryo suggests that deaths are widespread throughout blastocyst development of a number of species (Carnegie et al, 1985; Hardy et al, 1989; Enders et al, 1990), and may reach levels as high as $10 \%$ in the inner cell mass (El-Shershaby and Hinchliffe, 1974; Copp, 1978; Pierce et al, 1989). During mammalian gastrulation, significant numbers of cell deaths occur (Daniel and Olson, 1966; Poelmann and Vermeij-Keers, 1976; Lawson et al, 1986; Sanders et al, 1996) which may amount to some $15-20 \%$ of the total cell population.

In the chick embryo, where the process of gastrulation is more accessible to experimentation, cell death with apoptotic morphology is widespread (Bellairs, 1961), and recent detailed analysis (Sanders et al, 1996) indicates that it occurs in all germ layers throughout the embryo. There is a suggestion that cell death at this time is associated with the differentiation of the presumptive neural plate (Jacobson, 1938), but generally the relationship with morphogenesis is unclear.

Tumor necrosis factor-alpha (TNF- $\alpha$ ) is a multifunctional $17 \mathrm{kDa}$ peptide with well-established pathophysiological roles (Vassalli, 1992; Tracey and Cerami, 1994), including the ability to precipitate DNA fragmentation (Larrick and Wright, 1990; Wright et al, 1992), which is one of the main early characteristics of apoptotic cell death (Bortner et al, 1995). TNF- $\alpha$ exerts its effects through the activity of two distinct receptors, TNFR1 of $55-60 \mathrm{kDa}$ and TNFR2 of 75-80 kDa (Tartaglia et al, 1991), one or both of which are 
necessary for induction of apoptosis (Smith et al, 1994; Vandenabeele et al, 1995).

Because of the association of TNF- $\alpha$ with cell death, and because of the significance of cell death to developmental processes, we have previously speculated on possible developmental roles for TNF- $\alpha$ (Wride and Sanders, 1995). There is a growing body of literature to indicate that TNF- $\alpha$ mRNA and protein are widely expressed during the embryogenesis of the chick, mouse and human (Ohsawa and Natori, 1989; Gendron et al, 1991; Lachapelle et al, 1993; Hunt et al, 1993; Kohchi et al, 1994). In particular, TNF- $\alpha$ has been localized in gastrulating embryos (Wride and Sanders, 1993), and in several tissues during the next few days of development, including: myotome, neural tissue, notochord, lens, and lung (Wride and Sanders, 1993; Jaskoll et al, 1994). Further, during this period it is bioactive in eliciting cell death (Wride et al, 1994). Indeed, TNF- $\alpha$ appears to be one member of an array of cytokines present during early development that includes interleukins and interferon (Rothstein et al, 1992).

To what extent TNF- $\alpha$ has significant physiological roles during development remains unclear. Gene 'knockout' experiments (reviewed by Beutler, 1995), in which the receptors for TNF- $\alpha$ are deleted separately or in combination have yielded no gross developmental anomalies. Knockout of the TNF- $\alpha$ gene simultaneously with the lymphotoxin- $\alpha$ (TNF- $\beta$ ) gene results in developmental perturbation in the lymphoid system, but since knockout of lymphotoxin- $\alpha$ alone causes the same anomaly, this experiment does not provide evidence for a role for TNF- $\alpha$ in development. Similarly, a transgenic mouse line constitutively expressing an inhibitor of TNF- $\alpha$ and TNF- $\beta$ failed to produce anomalous phenotypes (Peppel et al, 1993). On the other hand, repeated injection of TNF- $\alpha$ antibodies into pregnant mice produces growth retardation and the development of abnormal lymphoid organs in the embryos (de Kossodo et al, 1992). Further, Vassalli (1993) has argued that the results of the TNF-receptor knockout experiments may not provide definitive evidence for roles for TNF- $\alpha$ itself, citing as confounding factors not only redundancy, but also the possibility of functions that are not mediated by the known receptors.

We have previously noted spatio-temporal correlations in the distribution of TNF- $\alpha$-related proteins and programmed cell death in the chick embryo (Wride et al, 1994). In the present work, we seek to substantiate a relationship between this factor and cell death in development, using the early chick embryo as a model. Since there is evidence that DNA fragmentation is an early event in programmed cell death during chick development (Toné et al, 1994), we assess cell death using the terminal deoxynucleotide transferase (TdT)-mediated dUTP-biotin nick-end-labelling (TUNEL) technique (Gavrieli et al, 1992; Wijsman et al, 1993). We give an account of the expression of TNF- $\alpha$ and its receptors during gastrulation, and take advantage of the accessibility of the chick embryo to provide experimental evidence for a role for this factor in the cell death that is occurring at this time in development.

\section{Results}

\section{Cell death in the gastrulating embryo}

We have recently carried out a detailed analysis of the distribution of nuclei undergoing DNA fragmentation and cell death during this developmental period in chick and mouse embryos (Sanders et al, 1996). Here, we summarize the situation for the chick in the context of the present work. Dying cells are apparent in all three germ layers of the embryo at this time, with particularly high numbers occurring in the epiblast. Especially notable was an arc of extensive cell death in the epiblast located in the rostral region of the embryo corresponding to the 'germinal crescent' (Figure 1a), and in the peripheral 'marginal zone', at the boundary between the area pellucida and the area opaca (Figure $1 \mathrm{~b}$ ). The primitive streak itself, and the tissues to either side of it, were generally regions of relatively low cell death, although local areas of higher cell death in the primitive streak could be found (Figure 1c).

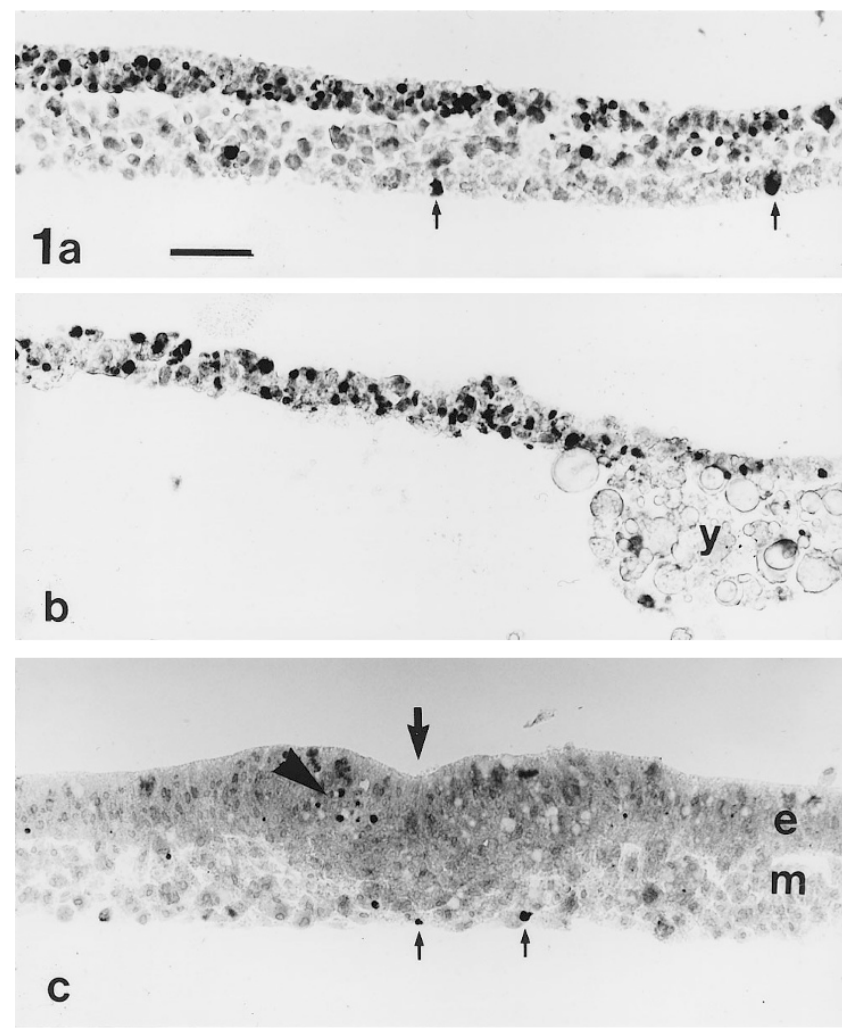

Figure 1 (a) Transverse section through the rostral region of the area pellucida of a stage 5 embryo, processed for the TUNEL technique to demonstrate nuclei undergoing DNA fragmentation. Positive nuclei are densely stained. In this region of the embryo, DNA fragmentation is extensive in nuclei of the upper epiblast layer, and scattered in nuclei in the middle mesoderm layer and the lower endoderm layer (arrows). Bar $=50 \mu \mathrm{m}$ in Figures 1-3. (b) As a, but through the peripheral region of the area pellucida, where it abuts the yolky area opaca (the marginal zone). TUNEL-positive nuclei are abundant in this region. $y=y o l k$. (c) As a, but through the primitive streak (large arrow). Nuclei showing DNA fragmentation are sparse in this region, although clusters of positive nuclei are seen in the streak itself (arrowhead). Only scattered positive nuclei are found throughout this region of the embryo, including the lower endoderm layer (small arrows). e=epiblast; $m=$ mesoderm. 


\section{Western blotting for TNF- $\alpha$}

We have previously shown that immunoblotting chick embryo homogenate with antibodies against mouse TNF- $\alpha$ gives rise to bands at a number of different molecular weights, notably $50 \mathrm{kDa}$ and $70 \mathrm{kDa}$ (Wride and Sanders, 1993). Using the modified methods described, and the polyclonal antibody, we now demonstrate a band at approximately $17 \mathrm{kDa}$ in homogenate of gastrulating embryos (Figure 2), corresponding to the molecular weight of native TNF- $\alpha$, in addition to the higher molecular weight forms that we described previously.

This method was also used to confirm that there was no detectable TNF- $\alpha$ present in the fetal bovine serum used for in vitro culture of cells (result not shown).

\section{Immunocytochemistry for TNF- $\alpha$, TNFR1 and TNFR2 in embryos}

During gastrulation, TNF- $\alpha$ was localized most intensely to the endoderm layer of cells (Figure 3a; monoclonal MP6 XT22) across the entire embryo, including the region immediately below the primitive streak. TNFR1 was localized to nuclei in cells of all layers of the embryo (Figure 3b), while TNFR2 was found primarily in endoderm layer (Figure 3c). The distribution of TNFR2 was not uniform in this layer, however, being present in the cytoplasm or on the surfaces of individual cells scattered within the endoderm. Immunoreactivity was particularly intense in endoderm cells at the lateral edges of the embryo where the endoderm approached the marginal zone (Figure 3d).

At stages of development earlier than gastrulation, these three antigens were detected only diffusely throughout the

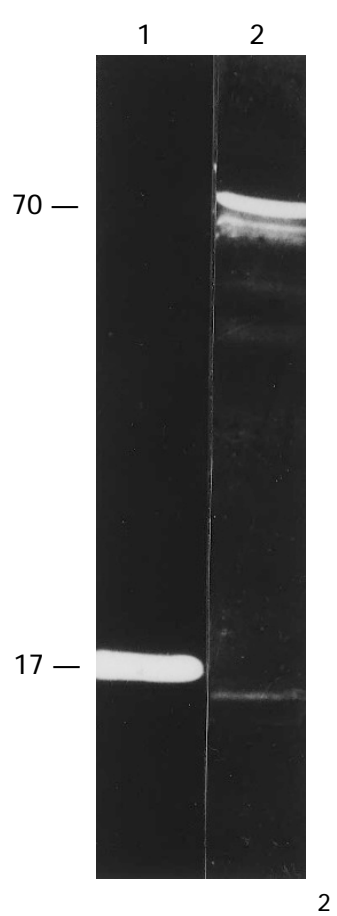

Figure 2 Western blot, showing recombinant TNF $\alpha$ running at $17 \mathrm{kDa}$ (lane 1). In whole homogenate of stage 5 embryos (lane 2) immunoreactive bands are found at approximately $17 \mathrm{kDa}$, as well as at $70 \mathrm{kDa}$. embryo, with TNFR1 again showing a preferential nuclear localization (not shown).

We have previously described the distribution of TNF- $\alpha$ in several tissues at later stages of development (Wride and Sanders, 1993). With regard to the receptor distributions, we found here that the immunoreactivity of both TNFR1 and TNFR2 declines immediately after gastrulation, with TNFR1 reoccurring first in well-defined locations, most notably in the myotome.

\section{Immunocytochemistry for bcl-2, Bax and ICE}

Because the $b c /-2$ and Bax gene products have been closely linked to the regulation of apoptotic cell death, often functioning through the action of interleukin- $1 \beta$-converting enzyme (ICE; Hockenbery, 1995), embryos were examined for the occurence of these proteins. Sections of embryos immunostained for these antigens showed widespread expression of both the $b c /-2$ and Bax gene products in all tissues. (Figure $3 e, f, g$ ). Immunoreactivity for ICE was not detected.

\section{Cell death in cultured cells}

When cultures of cells from the epiblast, mesoderm and endoderm of gastrulating embryos were examined for DNA fragmentation after 1 day in serum-free culture, very few cells were found to be TUNEL-positive (Figure 4a; Table 2). A correlation was noted, however, between cell detachment from the substratum and increased incidence of DNA fragmentation (Figure 4b).

\section{Immunocytochemistry for TNF- $\alpha$, TNFR1 and TNFR2 in cultured cells}

Localization of TNF- $\alpha$ to cytoskeletal stress fibres was found in cells from all of the three tissues using the monoclonal antibody MP6-XT22 (Figure 4c), and this was not affected by pre-absorption of the antibody with actin. Cell surfaces were immunoreactive, most noticeably with the polyclonal antibody (Figure 4d).

As in the sectioned material, TNFR1 was found to be associated with cell nuclei, and this relationship was strongest for cells of the endoderm (Figure 4e). TNFR2 distribution also supported the results on sectioned material, being localized to the cytoplasm in microfilaments (Figure 4f). This result was not affected by pre-absorption of the antibody with actin.

\section{Effects of TNF- $\alpha$ on cell death in embryos in culture (Table 1)}

Embryos cultured by the method of New (1955) for $6 \mathrm{~h}$ showed levels of DNA fragmentation which were similar to that observed in embryos of the same age taken directly from the egg. The addition of $10 \mu \mathrm{l}$ of saline to the exposed surface of the embryo during the incubation period did not change the incidence of TUNEL-positive nuclei (Figure 5a), which, in the region of the primitive streak, remained at very low levels. The addition of TNF- $\alpha$ at concentrations from $100-400 \mathrm{ng} / \mathrm{ml}$ for 

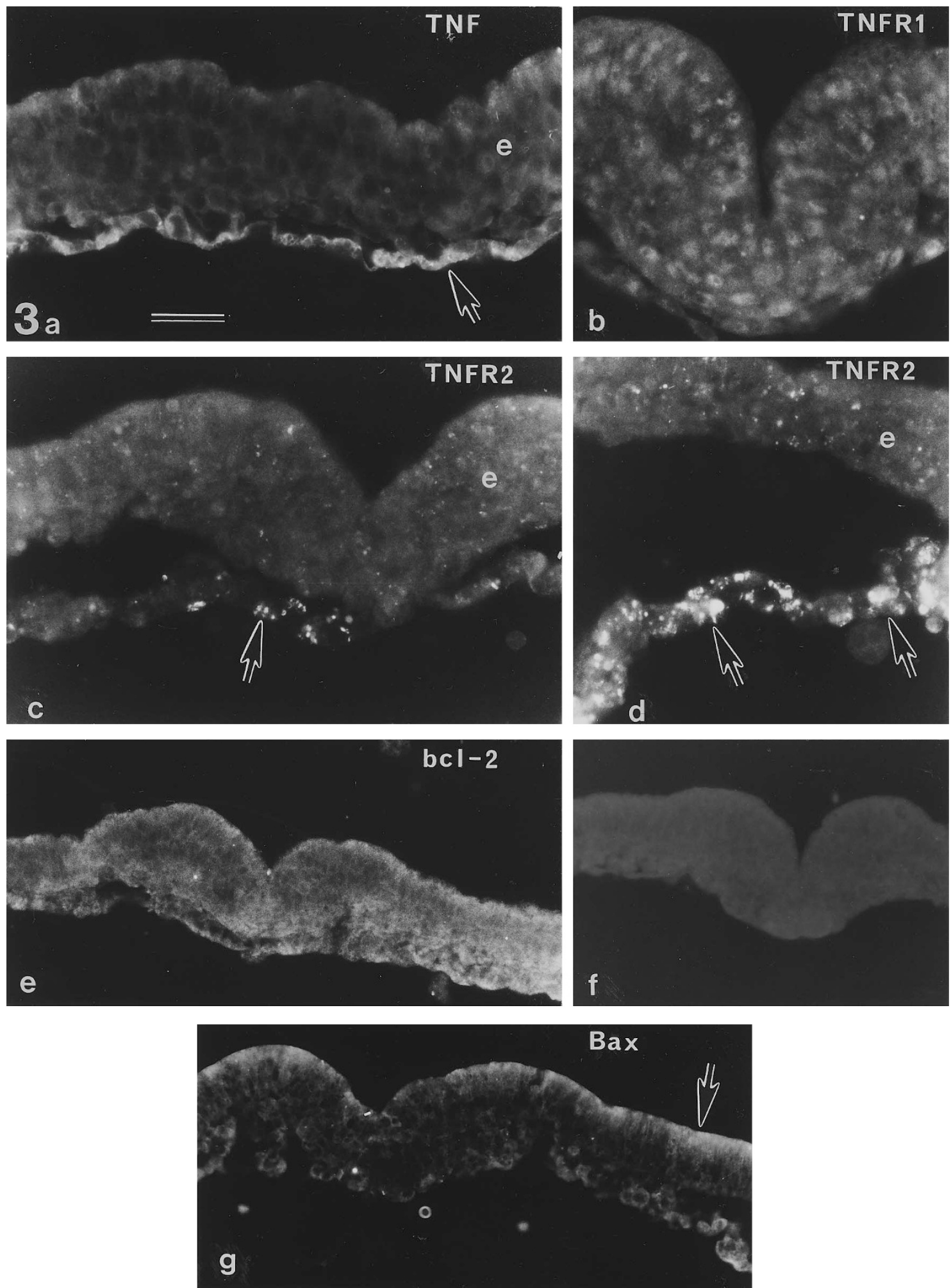

Figure 3 (a) Localization of TNF $\alpha$, showing intense immunoreactivity in the lower endoderm layer of cells (arrow). e=epiblast. Bar=50 $\mu \mathrm{m}$. (b) Localization of TNFR1, showing the nuclear localization of this receptor. Bar=50 $\mu \mathrm{m}$. (c) Localization of TNFR2, showing immunoreactivity in the endoderm close to the primitive streak (arrow). $e=e$ iblast. Bar $=50 \mu \mathrm{m}$. (d) Localization of TNFR2, showing intense immunoreactivity in the endoderm at the periphery of the area pellucida, in the marginal zone (arrows). e=epiblast. Bar=50 $\mu \mathrm{m}$. (e) Immunoreactivity for $b c l-2$ shows widespread distribution of this gene product throughout the embryo. Bar $=100 \mu \mathrm{m}$. (f) Control section, in which the antibody to $b c l-2$ was pre-absorbed with $b c l-2$ peptide. There is no labelling. Bar=100 $\mu \mathrm{m}$. (g) Immunoreactivity for Bax shows labelling throughout the embryo, but concentrated at the apical ends of the epiblast cells (arrow). Bar $=100 \mu \mathrm{m}$. 
$8 \mathrm{~h}$ also had no effect, however at $500 \mathrm{ng} / \mathrm{ml}$ for $8 \mathrm{~h}$ a highly significant increase in the incidence positive nuclei was observed (Table 1; Figure 5b). This increase was observed in all three tissue layers of the embryo, and in all regions of the blastoderm, but was not catastrophic in that no reproducible deleterious effect on development could be observed after treatment overnight $(n=10)$. This promotion of DNA fragmentation could be abolished by pre-absorption of the TNF- $\alpha$ with
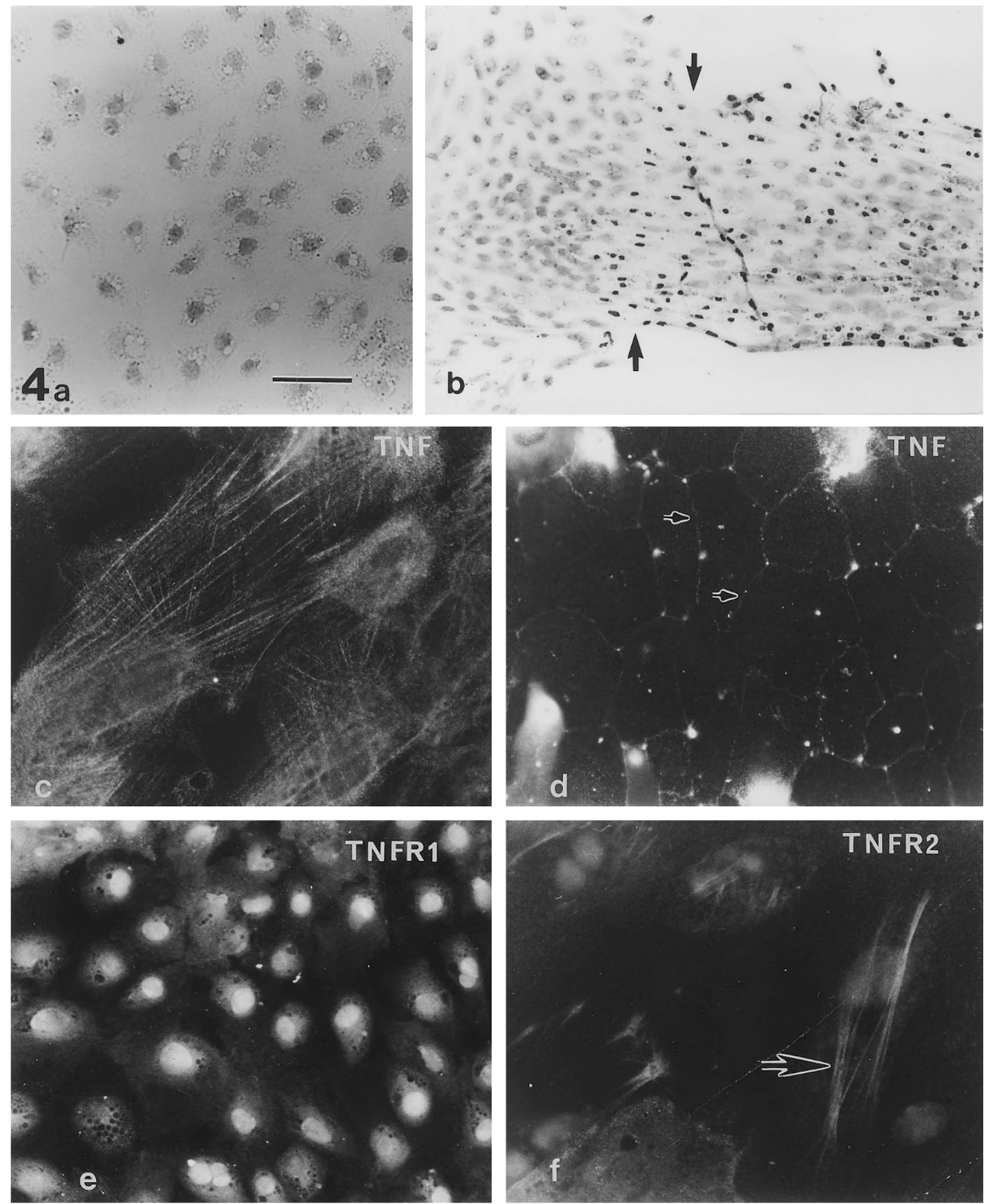

Figure 4 (a) A 2-day culture of untreated endoderm cells, showing that the nuclei of these cells are TUNEL-negative under these conditions. Bar=100 $\mu \mathrm{m}$. (b) As Figure (a), except that this untreated endoderm culture has partially detached from the substratum at the arrows. The part of the culture to the left is adherent to the substratum, and TUNEL-negative; the part of the culture to the right has partially detached, and is TUNEL-positive. Bar $=400 \mu \mathrm{m}$. (c) Localization of TNF $\alpha$ using monoclonal antibody in endoderm cultures shows immunoreactivity associated with the cytoskeleton. Bar $=50 \mu \mathrm{m}$. (d) Localization of TNF $\alpha$ using polyclonal antibody in endoderm cultures shows association with cell surfaces (arrows). Bar=100 $\mu \mathrm{m}$. (e) Localization of TNFR1 in endoderm cultures shows a nuclear localization of this receptor. Bar=100 $\mu \mathrm{m}$. (f) Localization of TNFR2 in endoderm cultures shows association of this receptor with the cytoskeleton (arrow). Bar $=50 \mu \mathrm{m}$ 
Table 1 Effects of TNF $\alpha$ on DNA fragmentation in intact embryos in culture

\begin{tabular}{lc}
\hline Treatment $(\mathbf{8} \mathbf{~ h})$ & DNA Fragmentation \\
\hline Saline & $1.30 \pm 1.17$ \\
TNF $\alpha(100 \mathrm{ng} / \mathrm{ml})$ & $1.19 \pm 0.72$ \\
TNF $\alpha(400 \mathrm{ng} / \mathrm{ml})$ & $0.74 \pm 0.85$ \\
TNF $\alpha(500 \mathrm{ng} / \mathrm{ml})$ & $6.16 \pm 4.15^{\star *}$ \\
Anti-TNF $\alpha$ PAb & $1.61 \pm 0.96$ \\
TNF $\alpha$ pre-absorbed $(500 \mathrm{ng} / \mathrm{ml})$ & $1.45 \pm 0.56$ \\
\hline
\end{tabular}

TUNEL-positive nuclei were scored in sections of embryos that had been cultured and treated with TNF $\alpha$ and its polyclonal antibody. The concentrations of TNF $\alpha$ shown were the initial concentrations applied. These concentrations were reduced during culture, by dilution, so that the effective concentration was reduced from $500 \mathrm{ng} /$ $\mathrm{ml}$ to approximately $110 \mathrm{ng} / \mathrm{ml}$. ${ }^{*}$ Significantly different from saline, $\mathrm{P}<0.01$.

Table 2 Analysis of cell cultures for TUNEL-positive nuclei

\begin{tabular}{llll}
\hline Treatment (8 h) & Endoderm & Mesoderm & Epiblast \\
\hline ITS & $0.12 \pm 0.05$ & $0.04 \pm 0.03$ & $0.06 \pm 0.06$ \\
TNF $\alpha(100 \mathrm{ng} / \mathrm{ml})$ & $0.21 \pm 0.21$ & $0.30 \pm 0.16$ & $0.22 \pm 0.25$ \\
$\mathrm{TNF} \alpha(500 \mathrm{ng} / \mathrm{ml})$ & $0.16 \pm 0.13$ & $0.68 \pm 0.85$ & $0.20 \pm 0.15$ \\
anti-TNF $\alpha \mathrm{MAb} 1$ & $9.66 \pm 5.58^{\star *} \dagger$ & $0.60 \pm 0.65^{\star} \dagger$ & $0.65 \pm .31^{\star} \dagger$ \\
anti-TNF $\alpha \mathrm{MAb} 2$ & $2.29 \pm 1.57^{\star} \dagger$ & $2.90 \pm 1.90^{\star} \dagger$ & $1.45 \pm 0.97^{\star} \dagger$ \\
anti-TNF $\alpha$ PAb & $0.69 \pm 0.75 \dagger$ & $1.01 \pm 0.28^{\star} \dagger$ & $0.88 \pm 0.37^{*} \dagger$ \\
anti-TNF r1 & $4.49 \pm 2.77^{\star *}$ & $5.32 \pm 4.2^{\star *}$ & $0.45 \pm 0.15^{\star}$ \\
anti-TNF r2 & $9.84 \pm 2.30^{\star *}$ & $8.38 \pm 2.56^{\star \star}$ & $6.83 \pm 1.40^{\star *}$ \\
\hline
\end{tabular}

In cultured tissues after treatment of the cultures with $\mathrm{TNF} \alpha$ and various antibodies to TNF $\alpha$. ITS ${ }^{T M}=$ defined control medium containing insulin, transferrin and selenium. Anti-TNF $\alpha$ MAb1=clone MP6-XT22 (Endogen/AbV); Anti-TNF $\alpha$ MAb2=clone MP8-XT22 (UBI); ${ }^{* *}=$ Significantly different from ITS, $\mathrm{P}<0.01 ;{ }^{*}=$ Significantly different from ITS $\mathrm{P}<0.05$; $\dagger=$ Labelled nuclei at the periphery of the culture; Mouse cells - ITS:0.43 \pm 0.11 ; $-\mathrm{TNF} \alpha(100 \mathrm{ng} / \mathrm{ml}): 0.56 \pm 0.18$

polyclonal antibody ( $1 \mu \mathrm{l}$ undiluted antiserum plus $50 \mu \mathrm{l}$ TNF- $\alpha, 500 \mathrm{ng} / \mathrm{ml}$ ), while the antibody alone at the same dilution was without effect (Table 1).

Measurements of the accumulation of fluid on the surface of embryos in culture indicated that during the $8 \mathrm{~h}$ incubation period, the test solution was being progressively diluted. The volume of fluid accumulated in this time was observed to be $34.4 \mu \mathrm{l}( \pm 8.1 ; n=10)$, meaning that during the incubation period, the TNF- $\alpha$ concentration fell from $500 \mathrm{ng} / \mathrm{ml}$ to $110 \mathrm{ng} / \mathrm{ml}$.

\section{Effects on cell death in cultured cells (Table 2)}

In contrast to the effects in embryo culture, TNF- $\alpha$, in a concentration series from $10-500 \mathrm{ng} / \mathrm{ml}$ had no effect on cell death in in vitro cultures of cells from any of the embryonic layers. Cultures were allowed to establish for $6 \mathrm{~h}$ before addition of the factor, and treatment was continued for varying periods up to 3 days before the cultures were assayed by the TUNEL method. In these experiments the cultures after treatment showed the same low levels of TUNEL-positive cells as in the controls (Figure 4a). In order to determine if this lack of effect was due to a species specific failure of mouse TNF- $\alpha$ to act on chick cells, this experiment was repeated using cultures of cells from mouse embryos at an equivalent stage of development. TNF- $\alpha$ was equally ineffective in eliciting DNA fragmentation in mouse cell cultures.
By contrast, monoclonal and polyclonal antibodies against TNF- $\alpha$ at $1: 10$ dilution caused statistically significant increases in the incidence of cell death, primarily affecting cells at the periphery of the culture (Figure $5 \mathrm{c}$ ). We have concluded that this non-uniform distribution of dying cells is related to effects of these antibodies on the detachment of marginal cells from the substratum (see below).

The addition of agonistic antibodies against TNFR1 and TNFR2 (1:150 and 1:120, respectively) resulted in highly significant increases in the occurrence of TUNEL-positive nuclei distributed throughout the cultures (Table 2). Of the two antibodies, the one against TNFR2 was the more effective (Figure 5d).

\section{Effects on cell proliferation in cultured cells}

In view of a recent report showing that TNF- $\alpha$ can stimulate cell proliferation in mouse primordial germ cells (Kawase et al. 1994), we tested for this effect in cultures of epiblast, mesoderm and endoderm cells. Although a substantial proportion of cells from each of the embryonic layers incorporated the BrdU label in untreated cultures (Figure $5 e)$, there was no significant effect of TNF- $\alpha$ or its antibodies on the rate of cell proliferation in these cultures. Quantification of proliferation was carried out and analyzed as for the TUNEL cultures.

\section{Relationship between cell adhesion and cell death}

In order to test the idea that a disruption in cell-to-substratum adhesion in vitro is able to induce DNA fragmentation in these cells, we cultured endoderm cells on a fibronectin substratum and treated the cultures with $\mathrm{V}_{2} \mathrm{E}_{9}$ monoclonal antibody to chicken integrin $\beta_{1}$ complex. Cultures were established in normal medium overnight, and then treated with supernatant overnight before fixing and taking through the TUNEL procedure. The treated cultures showed a significantly $(P<0.01)$ higher incidence of nuclei showing DNA fragmentation than controls cultured in the presence of non-specific mouse IgG $(0.07 \pm 0.06, n=10$; vs. $0.42 \pm 0.21, n=10)$.

\section{Discussion}

Although it is difficult to know if internucleosomal DNA fragmentation is invariably a feature of programmed cell death in development, it is generally regarded as a reliable, if not necessarily universal, characteristic of apoptosis (Compton, 1992; Bortner et al, 1995), so that use of the TUNEL technique as a marker for dying cells is an appropriate approach. Furthermore, in the early chick embryo, DNA fragmentation has been demonstrated in tissues known to be undergoing programmed cell death (Toné et al, 1994; Wride et al, 1994); cells die with the morphological features of apoptosis (Bellairs, 1961); and cells show antigenic determinants characteristic of apoptotic cells (Fernandez et al, 1994). Although not all programmed cell death occurs by apoptosis, evidence for non-apoptotic death in the early embryo is meagre (Sanders and Wride, 1995). Further, while DNA fragmentation also occurs in dividing cells, the levels of nick- 
end-labelling in these circumstances is comparatively low and does not obscure the relationship between fragmentation and cell death (Gold et al, 1993).

We have previously reviewed the evidence for a role for TNF- $\alpha$ in several different aspects of development, including cell death (Wride and Sanders, 1995), and we have drawn attention to spatio-temporal correlations between patterns of developmental cell death in the chick embryo and the distribution of TNF- $\alpha$ (Wride et al, 1994). Widely expressed in early development, TNF- $\alpha$ has been implicated not only in cell death, but also in muscle differentiation (Miller et al, 1988), organ branching morphogenesis (Jaskoll et al, 1994) and primordial germ cell proliferation (Kawase et al, 1994).

Although little is known of avian TNF- $\alpha$ itself (Qureshi et al, 1993; Zhang et al, 1995), it is known that this molecule is highly evolutionarily conserved (Ahne, 1994). We have shown earlier that several high molecular weight proteins present in the chick embryo are immunoreactive against antibodies to murine TNF- $\alpha$ (Wride and Sanders, 1993), and we show here that an approximately $17 \mathrm{kDa}$ immunoreactive protein, closely corresponding to the size of murine TNF- $\alpha$, is also present in the gastrulating chick embryo.

In the present study, we have shown that during gastrulation TNF- $\alpha$ and both of its receptors are found in the embryo. Whereas TNFR1 was found in cells throughout the embryo with a predominantly nuclear location, both TNF- $\alpha$ and TNFR2 were localized primarily to the endoderm, with this receptor being particularly abundant in cells of the marginal zone. The source of the TNF- $\alpha$ is unknown, so it is not clear if the endoderm is a site of synthesis, or a site of accumulation of TNF- $\alpha$ by the binding action of TNFR2. Examination of cultured cells clearly demonstrated the cell surface binding of TNF- $\alpha$ in all three cell types. The primary site of cell death at this time is the
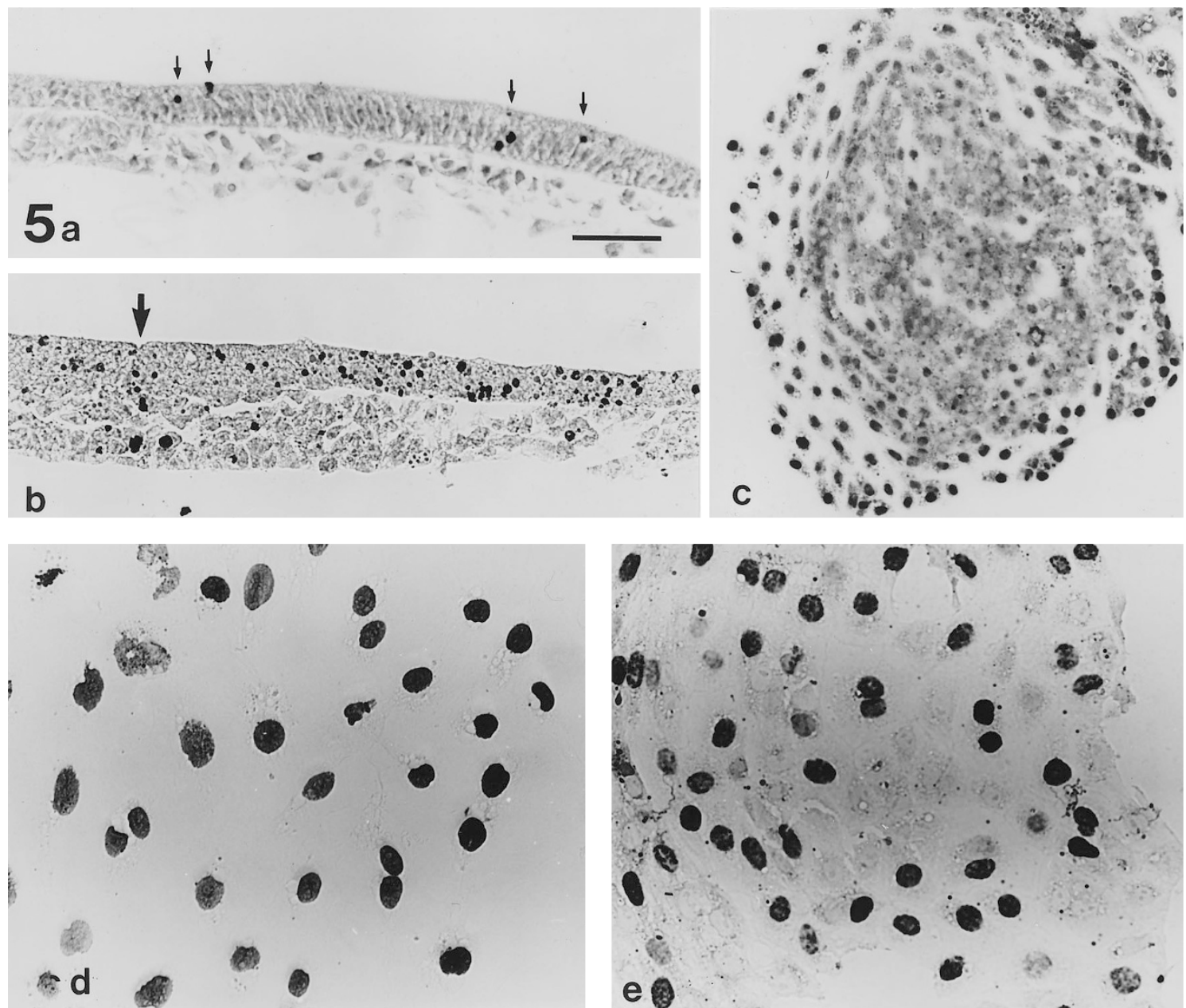

Figure 5 (a) Transverse section through a stage 5 embryo, close to the primitive streak, cultured for $6 \mathrm{~h}$ in the presence of saline. Few cells are TUNEL-positive (arrows; compare the frequency with that shown in Figure 3). Bar=400 $\mu \mathrm{m}$. (b) As Figure (a), but the embryo was treated with TNF $\alpha$ for $6 \mathrm{~h}$ (final concentration approximately $100 \mathrm{ng} / \mathrm{ml}$ ). There are large numbers of TUNEL-positive cells close to the primitive streak (arrow). Bar=400 $\mu \mathrm{m}$. (c) Endoderm culture treated with antibodies to TNF $\alpha$. TUNEL-positive cells are found primarily at the periphery of the culture. Bar $=400 \mu \mathrm{m}$. (d) Endoderm culture treated with antagonistic antibodies to TNFR2. A high proportion of cells are TUNEL-positive (see Table 2). Bar=100 $\mu \mathrm{m}$. (e) Endoderm culture treated with BrdU to assess the rate of cell proliferation. Many cells are proliferating, and this was not altered by treatment with TNF $\alpha$, its receptors, or their antibodies. Bar $=100 \mu \mathrm{m}$. 
epiblast, particularly in the marginal zone, with lesser amounts of death in each of the other cell layers (Sanders et al, 1996). It seems possible therefore that either the synthesis of TNF- $\alpha$ by the endoderm, or its binding there, acts as a trigger for cell death in cells in other cell layers of the embryo, most particularly in the marginal zone of the epiblast overlying the greatest localization of TNFR2. Since the vast majority of TNF- $\alpha$ produced by cells is secreted into the extracellular compartment (Beutler, 1995), paracrine control of cell death within the embryo is likely. Paracrine control of chick embryo differentiation by TNF- $\alpha$ has been suggested previously by Jaskoll et al (1994) in another context, and paracrine control of cell death in the mouse embryo by the HNF-4 transcription factor has also been speculated upon (Chen et al, 1994).

The triggering of DNA fragmentation in nuclei from all cell layers by application of exogenous TNF- $\alpha$ (at approximately $110 \mathrm{ng} / \mathrm{ml}$ ) in embryo cultures, indicates the capacity of many cells to respond to this factor, supporting the contention that TNF- $\alpha$ may be a physiological regulator of cell death in the embryo. TNF $\alpha$-like killing activity is found endogenously in chick embryos in the picogram range of concentrations (Wride et al, 1994).

Of the two receptors, it has generally been considered that TNFR1 mediates most of the known effects of TNF- $\alpha$ (Heller and Kronke, 1994), including cytotoxicity. TNFR2 has been considered more likely to be involved in the control of cell proliferation, and possibly involved only indirectly in cytotoxicity in co-operation with TNFR1 (Tartaglia and Goeddel, 1992). However, using agonistic antibodies against TNFR1 and TNFR2 on cell cultures, we found no influence on cell proliferation through TNFR2, instead, both receptors appeared to be involved in signalling cytotoxicity (see also Bazzoni et al, 1995). Indeed, the effect of TNFR2 in promoting cell death in cell cultures was more pronounced, and its distribution was more striking and localized, than that of TNFR1.

The widespread nuclear localization of TNFR1 in cells from all layers of the embryo both in tissue sections and in cell cultures, may reflect the nuclear translocation of this receptor after ligand engagement and internalization. It is becoming apparent that nuclear translocation of growth factors and their receptors may be a significant means of regulating the transcription of growth factor-responsive genes (Mason, 1994; Prochiantz and Theodore, 1995). The case has thus far been strongest for the nuclear action of fibroblast growth factor, which, after binding at the cell surface, appears to be targeted first to the perinuclear region and then to the nucleus itself. In the early chick embryo (Riese et al, 1995) FGF-2 isoforms are found in a predominantly nuclear location in pre-streak stages of development, but are found both in the nucleus and cytoplasm of the epiblast during gastrulation. Although the nuclear functions of FGF isoforms are unknown, it appears likely that there could be direct nuclear effects of these factors on cell proliferation of transcriptional regulation during differentiation. With respect to TNF- $\alpha$ and its receptors, our finding of a nuclear location for TNFR1 complements descriptions in other cells of its abundance in the peri-nuclear zone (Bradley et al, 1995), and the internalization and nuclear translocation of TNF- $\alpha$ itself, paralleling similar translocations of other cytokines such as interleukin-1 (Panagakos and Kumar, 1994). As in the case of FGF, the nuclear functions of TNF- $\alpha$ are as yet unknown.

We observed that the $b c l-2$ gene product appears to have a widespread distribution during gastrulation stages of development. This gene, and the related $b c l-x$, which are able to regulate cell survival by blocking pathways to programmed cell death (Reed, 1994; Hockenbery, 1995), are found to be expressed in a number of developmental situations in which cell death is a known contributor to morphogenesis (Eguchi et al, 1992; González-García et al, 1994; Novack and Korsmeyer, 1994). Further, in some situations, $b c l-2$ may be able to prevent TNF- $\alpha$-mediated cell death (Itoh et al, 1993; Vandenabeele et al, 1995) and in the present context might provide a means of controlling the action of TNF- $\alpha$, which is both widely distributed and potentially damaging to the embryo. Similarly, the Bax gene is found widely within the embryo, and it also is implicated in the control of cell death by dimerizing with, and thereby regulating the product of, bcl-2 (Korsmeyer et al, 1993). Although the protease, interleukin- $1 \beta$-converting enzyme (ICE) has been identified with TNF- $\alpha$-induced pathways to programmed cell death (Miura et al, 1995; Nicolson et al, 1995; Boudreau et al, 1995), we were unable to find its expression in gastrulating embryos. Recent work has shown, however, that ICE is but one member of an expanding family of cysteine proteases involved in cell death processes, so that the cell death described here may not require presence of ICE itself. These ICE-like proteases include, CPP-32, Mch2 and Mch3 (Orth et al, 1996), and we have found CPP-32 in avian embryonic tissue at later stages of development (unpublished), indicating its possible involvement.

The observation that TNF- $\alpha$ is effective in inducing DNA fragmentation in embryo culture but not in in vitro cell culture, suggests that cytotoxicity in vivo may be a synergistic effect involving cytokines working in concert with TNF- $\alpha$. One such possibility is an interaction between TNF- $\alpha$ and interferon- $\gamma$ (IFN- $\gamma$ ), which has been shown to be synergistic in the promotion of cytotoxicity in several other cell types (Jo et al, 1995; Kalovidouris and Plotkin, 1995). The availability of IFN- $\gamma$ during gastrulation has been demonstrated (Rothstein et al, 1992).

Our results provide support for the concept that cell death may be controlled in part by integrin-mediated signalling (Ruoslahti and Reed, 1994), and that the perturbation of cell adhesion can result in an apoptotic response (Bates et al, 1994; Boudreau et al, 1995; Hermiston and Gordon, 1995). We were able to increase levels of TUNEL-positive cells in cultures of endoderm cells, by the addition of anti- $\beta_{1}$ integrin antibodies to the medium. It is probable that such an effect is responsible for the high levels of cell death observed locally in some regions of the primitive streak (Sanders et al, 1996), where changes in integrin engagement accompany the epithelialto-mesenchymal transformation that occurs as cells traverse the primitive streak and change their primary substratum from laminin and collagen IV to fibronectin and hyaluronan (Sanders, 1986). 
Further, it is likely that an adhesion-mediated effect on cell death is responsible for the increased levels of TUNEL-positive cells observed here in cell cultures, but not in embryo cultures, upon application of anti-TNF- $\alpha$ antibodies. We found (Table 2 ) that both monoclonal and polyclonal antibodies to TNF- $\alpha$ elicited this response to varying degrees. The relationship between TNF- $\alpha$ and cell adhesion is clear from reports indicating that this cytokine is capable of regulating integrin expression (Santala and Heino, 1991; DeFilippi et al, 1992), and can interact with extracellular matrix molecules including fibronectin (Alon et al, 1994; Coito et al, 1995) and laminin (Alon et al, 1994; Hershkoviz et al, 1995). These effects of TNF- $\alpha$ can result in modulation of cell adhesion to various matrix substrata, and may explain the tendency of anti-TNF- $\alpha$ antibodies to cause detachment of these embryonic cells from fibronectin and the consequent increase in DNA fragmentation. Also in this connection, we have shown an association between the distribution of $\mathrm{TNF}-\alpha$ and TNFR2 and the cytoskeleton, suggesting that these antibodies may perturb adhesiveness through an effect on actin microfilaments. Again, there is evidence for interactions between TNF- $\alpha$ and the actin cytoskeleton, with consequent effects on cell adhesion in a number of other cell types (Kohno et al, 1993; Deli et al, 1995; Tabibzadeh et al, 1995).

In summary, we have provided evidence for a potential role for TNF- $\alpha$ and its receptors in the early differentiation of the chick embryo. The pleioptoic effects of this cytokine, which is expressed at various times during development, suggest that it may modulate programmed cell death in the embryo, either by activating cell death signalling pathways directly, or indirectly through perturbation of integrinmediated cell adhesion and the interaction of cells with their extracellular matrices.

\section{Materials and Methods}

Gastrulating White Leghorn chick embryos, at stage 4-5 of Hamburger and Hamilton (1951), were freed from their yolk and handled in Pannett and Compton's saline or in Tyrode's saline. For whole embryo culture, embryos were explanted according to the method of New (1955), using a $25 \mathrm{~mm}$ internal diameter glass ring for support. Embryos were cleaned of yolk using saline washes, and the test solutions $(10 \mu \mathrm{l})$ were added to the exposed surface of the endoderm. The whole embryo cultures were incubated for the requisite length of time at $37^{\circ} \mathrm{C}$ in a humidified $\mathrm{CO}_{2}$ incubator.

For cell culture, embryos were dissected using fine tungsten needles, without the aid of enzymatic digestion, to give tissues from the epiblast, mesoderm and endoderm layers. These tissues were explanted in medium 199 with antibiotics onto fibronectin-coated glass coverslips contained in $35 \mathrm{~mm}$ diameter plastic petri dishes. The culture medium was supplemented with either $1 \%$ fetal bovine serum or with ITS $+{ }^{\mathrm{TM}}$ (Insulin, Transferrin and Selenium; Becton Dickinson Labware) at a concentration of $10 \mu \mathrm{l}$ stock solution per $1 \mathrm{ml}$ of medium 199. Cultures were incubated for the requisite length of time at $37^{\circ} \mathrm{C}$ in a humidified $\mathrm{CO}_{2}$ incubator.
Embryos were prepared for sectioning by fixing with 4\% paraformaldehyde in $0.1 \mathrm{M}$ phosphate buffered saline (PBS) overnight at $4^{\circ} \mathrm{C}$, washing in PBS (pH 7.4), dehydrating through a graded series of ethanol, clearing in Hemo-De (Fisher Scientific) and embedding in paraffin wax. Blocks were sectioned at $8 \mu$ thickness.

\section{The TUNEL technique}

Incorporation of biotinylated nucleotides at free $3^{\prime}-\mathrm{OH}$ ends of DNA in tissue sections was carried out as described by Gavrieli et al (1992) with modifications according to Wijsman et al (1993). Sections were cleared in Hemo-De $(2 \times 5$ mins $)$, rehydrated through a graded series of alcohol, and were immersed in double distilled water (DDW). Sections were then incubated for $20 \mathrm{~min}$ in $2 \times \mathrm{SSC}$ buffer $(0.3 \mathrm{M}$ sodium chloride, $30 \mathrm{mM}$ sodium citrate, $\mathrm{pH} 7$ ) at $60^{\circ} \mathrm{C}$, washed in $\mathrm{DDW}$, and incubated in proteinase $\mathrm{K}$ buffer $(10 \mathrm{mM}$ Tris- $\mathrm{HCl}$, $\mathrm{pH} 8$ ) for $10 \mathrm{~min}$ at room temperature. This was followed by incubation with $2.5 \mu \mathrm{g} / \mathrm{ml}$ of freshly prepared proteinase $\mathrm{K}$ (Sigma) in $10 \mathrm{mM}$ Tris $/ \mathrm{HCl}, \mathrm{pH} 8.0$, for $7.5 \mathrm{~min}$ at room temperature, and a final wash in DDW. Endogenous peroxidase was inactivated by incubating the sections with $2 \%$ hydrogen peroxide in DDW, with $0.5 \%$ Tween 20 for $10 \mathrm{~min}$ at room temperature. This was followed by a wash in DDW for $5 \mathrm{~min}$. Sections were then incubated in TdT buffer, $\mathrm{pH} 7.2$ (30 mM Trizma base, $140 \mathrm{mM}$ sodium cacodylate, $1 \mathrm{mM}$ cobalt chloride) for $5 \mathrm{~min}$ at room temperature. The reaction mixture was prepared as follows, using components from the terminal transferase kit supplied by BoehringerMannheim, allowing approximately $80 \mu \mathrm{l}$ for each slide: DDW, $65.6 \mu \mathrm{l}$; TdT buffer, $5.2 \mu \mathrm{l}$; cobalt chloride, $2.6 \mu \mathrm{l}$; biotin-16dUTP stock $(1 \mathrm{nmol} / \mu \mathrm{l}), 1.48 \mu \mathrm{l}$; dUTP, $4.4 \mu \mathrm{l}$; and TdT (10 units $/ \mu \mathrm{l}), 1.6 \mu \mathrm{l}$. The sections were exposed to reaction mixture and incubated at $37^{\circ} \mathrm{C}$ for $1.5 \mathrm{~h}$ in a humid chamber. The reaction was terminated by immersion of the slides in $2 \times$ SSC at room temperature for $15 \mathrm{~min}$. Following two further washes in PBS (Ph 7.4), the sections were covered in $3 \%$ skimmed milk (SM) in PBS with $0.5 \%$ Tween 20 for 15 min to block non-specific binding. Following this, excess SM was removed and sections were incubated with Extra-avidin-peroxidase ${ }^{\circledR}$ (Sigma), diluted 1:50 in 3\% SM in PBS with $0.5 \%$ Tween 20 , for $30 \mathrm{~min}$ at room temperature. Slides were then washed in PBS, and sections were stained using the AEC procedure (Pierce). Stock AEC solution was prepared by dissolving $A E C$ in dimethyl formamide to a final concentration of $4 \mathrm{mg} / \mathrm{ml}$. Prior to the color reaction, $0.67 \mathrm{ml}$ of AEC stock was added to $10 \mathrm{ml}$ of $0.1 \mathrm{M}$ sodium acetate buffer, $\mathrm{pH} 5.2$ and $10 \mu \mathrm{l}$ of $30 \% \mathrm{H}_{2} \mathrm{O}_{2}$ was then added. This solution was filtered and applied to the sections which were monitored under a microscope until the color reaction was optimal. The slides were then washed in PBS and mounted in Crystal Mount ${ }^{\mathbb{B}}$ (Fisher Scientific Inc.). Positively stained nuclei were colored intensely red.

In addition, both positive and negative controls were performed. In the negative controls either the bio-16-dUTP stock or the TdT enzyme was omitted from the reaction mixture. For positive controls, sections were treated with DNAsel buffer (30 mM Trizma base, $140 \mathrm{mM}$ sodium cacodylate, $4 \mathrm{mM}$ magnesium chloride, $0.1 \mathrm{mM}$ dithiothrei- 
tol) for $5 \mathrm{~min}$ following the quenching of endogenous peroxidase, incubated with fresh DNAsel $(1 \mu \mathrm{g} / \mathrm{ml}$; Boehringer Mannheim) in buffer for $10 \mathrm{~min}$ at room temperature, and then washed in DDW. Processing of the sections was then continued as described above. In negative control slides, no staining was observed in any of the nuclei and the light pink background color was identical to that observed in experimental sections. In positive control sections treated with DNAsel, every nucleus was stained intensely red.

For cultures, the TUNEL method was carried out as above. Fixed cultures were washed with PBS and the procedure was started at the hydrogen peroxide step to inactivate endogenous peroxidase, having not been treated with proteinase $\mathrm{K}$.

\section{Sources of reagents}

Recombinant murine TNF- $\alpha$ was obtained from Genzyme Corp. Antibodies against murine TNF- $\alpha$ were obtained from: Genzyme Corp. (polyclonal); Upstate Biotechnology Inc., (monoclonal, clone MP8 XT22); abV ImmuneResponse Inc., Endogen Inc., and Gibco-BRL (monoclonal, clone MP6 XT22). Agonistic polyclonal antibodies (Tartaglia et al, 1991) against murine TNFR1 and TNFR2 were obtained from Genentech Inc. and Santa Cruz Biotechnology Inc. Bromodeoxyuridine (BrdU) was obtained from Sigma and a monoclonal antibody against BrdU was obtained from Amersham Life Science Inc. Monoclonal antibody to chicken integrin $\beta_{1}$ complex, $\left(\mathrm{V}_{2} \mathrm{E}_{9}\right)$, was obtained from the Developmental Studies Hybridoma Bank. Polyclonal antibodies to amino acid sequences from bcl-2 (\#SC-492), Bax (\#SC-493) and ICE (\#SC-514), together with their control peptides, were obtained from Santa Cruz Biotechnology Inc.

\section{Immunocytochemistry}

Sections were de-waxed, rehydrated, and treated with $1 \%$ or $4 \%$ bovine serum albumin (BSA) in PBS to block non-specific staining. Primary antibodies were applied at dilutions of between $1: 50$ and $1: 200$ in PBS plus BSA for $1-2 \mathrm{~h}$. For immunolabelling with antibodies to $b c l-2, B a x$ and ICE, antibodies were applied at a dilution of $1: 100$ at $4^{\circ} \mathrm{C}$ overnight. After washing several times with PBS plus BSA an appropriate second antibody, labelled with fluorescein isothiocyanate, was applied at a dilution of $1: 100$ for $1 \mathrm{~h}$. Slides were finally washed with PBS and mounted.

Cultures were fixed overnight with $4 \%$ formaldehyde, and then washed with PBS plus BSA containing 0.5\% Tween 20 to permeabilize the cells. Cultures were then treated as above.

In control slides, the primary antibody was replaced by PBS and either rabbit serum, for polyclonal antibodies, or mouse IgG for monoclonal antibodies. In the case of $b c l-2$, Bax and ICE antibodies, a pre-absorption control was carried out using the peptide provided with the antibody (peptide:antibody::1:1, final antibody concentration $1: 100$ ). In all cases, the control slides showed very low levels of non-specific background staining which was clearly distinguishable from the staining of the experimental slides.

\section{Western blotting}

Polyacrylamide gel electrophoresis was carried out as described previously (Wride and Sanders, 1993), except that embryos were homogenized in a buffer containing protease inhibitors as described by Jaskoll et al (1994). Western blotting was also carried out as described previously, except that bands were detected using an enzyme chemiluminescence kit obtained from Amersham Life Science Inc.

\section{Mouse cell culture}

Mouse embryo at the early- to mid-primitive streak stage (Downs and Davies, 1993) were obtained from timedpregnant females. Embryos were finely minced with tungsten needles, and the pieces explanted into 199 culture medium with antibiotics and $1 \%$ fetal bovine serum. Cultures were incubated as described above. No attempt was made to separate embryonic germ layers in these cultures.

\section{Bromodeoxyuridine (BrdU) incorporation}

Cell cultures were grown overnight on fibronectin-coated coverslips as described above. Next day, the medium was replaced with medium containing $10 \mu \mathrm{g} / \mathrm{ml}$ BrdU, and the cultures were incubated for a further $2 \mathrm{~h}$ before rising with Tyrode's saline and fixing overnight. After rinsing with PBS, cultures were treated with $1 \%$ hydrogen peroxide in $50 \%$ methanol for $30 \mathrm{~min}$, followed by another wash with PBS. Following treatment with $1 \%$ BSA and $0.1 \%$ Tween 20 in PBS for $30 \mathrm{~min}$, cultures were incubated with monoclonal antibody to BrdU, undiluted, for $1 \mathrm{~h}$. Controls were incubated with PBS. Cultures were washed with $1 \% \mathrm{BSA}$, incubated with biotinylated goat anti-mouse IgG, washed again, and treated with Extra-Avidin peroxidase (Sigma), diluted 1:50 in PBS containing $4 \%$ BSA, for 30 min. Colour was developed using the AEC procedure as described above.

\section{Quantification of TUNEL and BrdU labelling}

Cultures, with cell nuclei labelled using either the TUNEL or BrdU incorporation procedures, were quantified using the 'Image-1' image analysis system (Universal Imaging Corp, West Chester, PA), and a Zeiss Axioskop microscope. The image was captured and thresholded to highlight only structures stained to an appropriate density, and the 'shape factor' was adjusted so that only labelled nuclei were counted as a function of culture area. Results were expressed as the number of labelled nuclei per standard, but arbitrary, area of spread cells, and were analyzed for statistical significance using an unpaired t-test.

Analysis of the incidence of nuclei undergoing DNA fragmentation in sections of embryos that had been treated while in culture by the method of New (1955), was carried out as above by expressing the number of TUNEL-positive nuclei per area of tissue in sections of standard thickness $(5 \mu \mathrm{m})$. These sections were always taken from the same level of the embryo - midway along the primitive streak and always encompassed the same section width, 
including the entire primitive streak and a $60 \mu \mathrm{m}$ stretch of tissue to one side of the streak, similar to the region shown in Figure $5 \mathrm{~b}$.

\section{Acknowledgements}

We thank the Medical Research Council of Canada for an operating grant in support of this work, and the Alberta Heritage Foundation for Medical Research for a studentship to MAW. We also thank the Developmental Studies Hybridoma Bank, maintained by the Department of Pharmacology and Molecular Sciences, Johns Hopkins University School of Medicine, Baltimore, and by the Department of Biological Sciences, University of lowa, lowa City, under contract from the NICHD.

\section{References}

Ahne W (1994) Evidence for the early appearance of interleukins and tumor necrosis factor in the phylogenesis of vertebrates. Immunol. Today 15: 137

Alon R, Cahalon L, Hershkoviz R, Elbaz D, Reizis B, Wallach D, Akiyama SK, Yamada KM and Lider O (1994) TNF- $\alpha$ binds to the N-terminal domain of fibronectin and augments the $\beta_{1}$-integrin-mediated adhesion of $\mathrm{CD} 4^{+} \mathrm{T}$ lymphocytes to the glycoprotein. J. Immunol. 152: 1304-1313

Bates RC, Buret A, van Helden DF, Horton MA and Burns GF (1994) Apoptosis induced by inhibition of intercellular contact. J. Cell Biol. 125: 403-415

Bazzoni F, Alejos E and Beutler B (1995) Chimeric tumor necrosis factor receptors with constitutive signaling activity. Proc. Natl. Acad. Sci. USA 92: 5376-5380

Bellairs R (1961) Cell death in chick embryos as studied by electron microscopy. J. Anat. 95: 54-63

Beutler B (1995) TNF, immunity and inflammatory disease: lessons of the past decade. J. Inv. Med. 43: 227-235

Bortner CD, Oldenburg NBE and Cidlowski JA (1995) The role of DNA fragmentation in apoptosis. Trends Cell Biol. 5: 21-26

Boudreau N, Sympson CJ, Werb Z and Bissell MJ (1995) Suppression of ICE and apoptosis in mammary epithelial cells by extracellular matrix. Science 267:891 893

Bradley JR, Thiru S and Pober JS (1995) Disparate localization of 55-kd and 75-kd tumor necrosis factor receptors in human endothelial cells. Am. J. Pathol. 146: $27-32$

Carnegie JA, McCully ME and Robertson HA (1985) The early development of the sheep trophoblast and the involvement of cell death. Am. J. Anat. 174: 471-488

Chen WS, Manova K, Weinstein DC, Duncan SA, Plump AS, Prezioso VR, Bachvarova RF and Darnell JE Jr (1994) Disruption of the HNF-4 gene, expressed in visceral endoderm, leads to cell death in embryonic ectoderm and impaired gastrulation of mouse embryos. Genes Dev. 8: 2466-2477

Coito AJ, Binder J, Brown LF, de Sousa M, Van De Water Land Kupiec-Weglinski JW (1995) Anti-TNF- $\alpha$ treatment down-regulates the expression of fibronectin and decreases cellular infiltration of cardiac allografts in rats. J. Immunol. 154:2949 2958

Compton MM (1992) A biochemical hallmark of apoptosis: internucleosomal degradation of the genome. Canc. Metas. Rev. 11: 105-119

Copp AJ (1978) Interaction between innercell mass and trophectoderm of the mouse blastocyst. I. A study of cellular proliferation. J. Embryol. Exp. Morph. 48: 109125

Daniel JC and Olson JD (1966) Cell movement, proliferation and death in the formation of the embryonic axis of the rabbit. Anat. Rec. 156: 123-128

DeFilippi P, Silengo L and Tarone G (1992) $\alpha 6 \bullet \beta 1$ integrin (laminin receptor) is-downregulated by tumor necrosis factor $\alpha$ and interleukin- $1 \alpha$ in human endothelial cells. J. Biol. Chem. 267: 18303-18307

de Kossodo S, Grau GE, Daneva T, Pointaire P, Fossati L, Ody C, Zapf J, Piguet P-F, Gaillard RC and Vassalli P (1992) Tumor necrosis factor $\alpha$ is involved in mouse growth and lymphoid tissue development. J. Exp. Med. 176: 1259-1264

Deli MA, Decamps L, Dehouck M-P, Cecchelli R, Joó F, Ábrahám CS and Torpier G (1995) Exposure of tumor necrosis factor- $\alpha$ to luminal membrane of bovine brain capillary endothelial cells cocultured with astrocytes induces a delayed increase of permeability and cytoplamic stress fiber formation of actin. J. Neurosci. Res. $41: 717-726$
Downs KM and Davis T (1993) Staging of gastrulating mouse embryos by morphological landmarks in the dissecting microscope. Development, 118: $1255-1266$

Eguchi Y, Ewart DL and Tsujimoto Y (1992) Isolation and characterization of the chicken $b c l-2$ gene: expression in a variety of tissues including lymphoid and neuronal organs in adult and embryo. Nucl. Acids Res. 20: 4187-4192

El-Shershaby AM and Hinchliffe JR (1974) Cell redundancy in the zona-intact preimplantation mouse blastocyst, a light and electron microscope study of dead cells and their fate. J. Embryol. Exp. Morph. 31: 643-654

Enders AC, Lantz KC and Schlafke S (1990) Differentiation of the inner cell mass of the baboon blastocyst. Anat. Rec. 226: 237-248

Ferguson MJW (1988) Palate development. Development, 103 Suppl: 41-60

Fernandez P-A, Rotello RJ, Rangini Z, Doupe A, Drexler HCA and Yuan J (1994) Expression of a specific marker of avian programmed cell death in both apoptosis and necrosis. Proc. Natl. Acad. Sci. USA 91: 8641-8645

Gavrieli Y, Sherman Y and Ben-Sassoon SA (1992) Identification of programmed cell death in situ via specific labeling of nuclear DNA fragmentation. J. Cell Biol. 119: 493-501

Gendron RL, Nestel FP and Lapp WS (1991) Expression of tumor necrosis factoralpha in the developing nervous system. Int. J. Neurosci. 60: 129-136

Glücksmann A (1951) Cell deaths in normal vertebrate ontogeny. Biol. Rev. Camb. Phil. Soc. 26: 59-86

Gold R, Schmied M, Rothe G, Zischler H, Breitschopf H, Wekerle H and Lassmann H (1993) Detection of DNA fragmentation in apoptosis: application of in situ nick translation to cell culture systems and tissue sections. J. Histochem. Cytochem. 41: $1023-1030$

González-García M, Pérez-Ballestero R, Ding L, Duan L, Boise LH, Thompson CB and Núñez $G$ (1994) $b c l-\alpha_{L}$ is the major $b c l-\alpha$ mRNA form expressed during murine development and its product localizes to mitochondria. Development, 120: $3033-3042$

HamburgerV and Hamilton HL (1951) A series of normal stages in the development of the chick embryo. J. Morphol. 88: 49-92

Hardy K, Handyside AH and Winston RL (1989) The human blastocyst, cell number, death and allocation during late pre-implantation development in vitro. Development, 107: 597-604

Heller RA and Krönke M (1994) Tumor necrosis factor receptor-mediated signaling pathways. J. Cell Biol. 126: 5-9

Hermiston ML and Gordon JI (1965) In vivo analysis of cadherin function in the mouse intestinal epithelium: essential roles in adhesion, maintenance of differentiation, and regulation of programmed cell death. J. Cell Biol. 129: 489-506

Hershkoviz R, Goldkorn I and Lider P (1995) Tumor necrosis factor- $\alpha$ interacts with laminin and functions as a pro-adhesive cytokine. Immunology 85: 125-130

Hinchliffe JR (1981) Cell death in embryogenesis. In: Cell Death in Biology and Pathology. (ID Bowen and RA Lockshin, eds.), Chapman and Hall, London. pp. $35-78$

Hockenbery DM (1995) bcl-2, a novel regulator of cell death. BioEssays 17: 631 638

Homma S, Yaginuma Hand Oppenheim RL (1994) Programmed cell death during the earliest stages of spinal cord development in the chick embryo, a possible means of early phenotypic selection. J. Comp. Neurol. 345: 377-395

Hunt JS, Chen H-L, Hu X-L and Pollard JW (1993) Normal distribution of tumor necrosis factor- $\alpha$ messenger ribonucleic acid and protein in the uteri, placentas, and embryos of osteopetrotic (op/op) mice lacking colony-stimulating factor-1. Biol. Reprod. 49: 441-452

Itoh N, Tsujimoto Y and Nagata S (1993) Effect of bcl-2 on Fas antigen-mediated cell death. J. Immunol. 151:621-627

Jacobson W (1938) The early development of the avian embryo. II. Mesoderm formation and the distribution of presumptive embryonic material. J. Morphol. 62 445-501

Jaskoll T, Boyer PD and Melnick M (1994) Tumor necrosis factor- $\alpha$ and embryonic mouse lung morphogenesis. Dev. Dynam. 201: 137-150

Jeffs $P$, Jaques $K$ and Osmond $M$ (1992) Cell death in cranial neural crest development. Anat. Embryol. 185: 583-588

Jo T, Tomiyama T, Ohashi K, Saji F, Tanizawa O, Ozaki M, Yamamoto R, Yamamoto T, Nishizawa Y and Terada N (1995) Apoptosis of cultured mouse luteal cells induced by tumor necrosis factor- $\alpha$ and interferon- $\gamma$. Anat. Rec. 241: 70-76

Kalovidouris AE and Plotkin Z (1995) Synergistic cytotoxic effects of interferon- $\gamma$ and tumor necrosis factor- $\alpha$ on cultured human muscle cells. J. Rheumatol. 22 : $1698-1703$ 
Kawase E, Yamamoto H, Hashimoto Kand Nakatsuji N (1994) Tumornecrosis factor$\alpha$ (TNF- $\alpha$ ) stimulates proliferation of mouse primordial germ cells in culture. Dev. Biol. 161: 91-95

Kohchi C, Naguchi K, Tanabe Y, Mizuno D-I and Soma G-I (1994) Constitutive expression of TNA- $\alpha$ and $-\beta$ genes in mouse embryo: roles of cytokines as regulator and effector on development. Int. J. Biochem. 26: 111-119

Kohno K, Hamanaka R, Abe T, Nomura Y, Morimoto A, Izumi H, Shimizu K, Ono Mand Kuwano M (1993) Morphological changes and destabilization of $\beta$-actin mRNA by tumor necrosis factor in human microvascular endothelial cells. Exp. Cell Res 208: $498-503$

Korsmeyer SJ, Shutter JR, Veis DJ, Merry DE and Oltvai ZN (1993) Bcl-2/Bax: a rheostat that regulates an anti-oxidant pathway and cell death. Sem. Canc. Biol. 4: $327-332$

Lachapelle MH, Miron P, Hemmings R, Falcone T, Granger L, Bourque J and Langlais $J$ (1993) Embryonic resistance to tumor necrosis factor- $\alpha$ mediated cytotoxicity: novel mechanism underlying maternal immunological tolerance to the fetal allograft. Human Reprod. 8: 1032-1038

Larrick JW and Wright SC (1990) Cytotoxic mechanisms of tumor necrosis factor- $\alpha$ FASEB J. 4: 3215-3323

Lawson KA, Meneses JJ and Pedersen RA (1986) Cell fate and cell lineage in the endoderm of the presomite mouse embryo, studied with an intracellular tracer. Dev. Biol. 115: 326-339

Mason JJ (1994) The ins and outs of fibroblast growth factors. Cell 78: 547-552

Miller SC, Ito H, Blau HM and Torti FM (1988) Tumor necrosis factor inhibits human myogenesis in vitro. Mol. Cell. Biol. 8: 2295-2301

Miura M, Friedlander RM and Yuan J (1995) Tumor necrosis factor-induced apoptosis is mediated by a CrmA-sensitive cell death pathway. Proc. Natl. Acad. Sci. USA. 92: 8318-8322

New DAT (1955) A new technique for the cultivation of the chick embryo in vitro. J. Embryol. Exp. Morph. 3: 320-331

Nicolson DW and 15 others (1995) Identification and inhibition of the ICE/CED-3 protease necessary for mammalian apoptosis. Nature 376: 37-42

Novack DV and Korsmeyer SJ (1994) Bcl-2 protein expression during murine development. Am. J. Pathol. 145: 61-73

Ohsawa T and Natori S (1989) Expression of tumor necrosis factor at a specific developmental stage of mouse embryos. Dev. Biol. 135: 459-461

Orth K, Chinnaiyan AM, Garg M, Froelich CJ and Dixit VM (1996) The CED-3/ICE-like protease Mch2 is activated during apoptosis and cleaves the death substrate lamin A. J. Biol. Chem. 271: 16443-16446

Panagakos FS and Kumar S (1994) Nuclear localization of tumor necrosis factoralpha in human osteoblast-like cells. Biochem. Biophys. Res. Comm. 201 $1445-1450$

Peppel K, Poltorak A, Melhado I, Jirik F and Beutler B (1993) Expression of a TNF inhibitor in transgenic mice. J. Immunol. 151: 5699-5703

Pexieder T (1975) Cell death in the morphogenesis and teratogenesis of the heart. Adv. Anat. Embryol. Cell Biol. 51: 1-100

Pierce GB, Lewellyn AL and Parchment RE (1989) Mechanism of programmed cell death in the blastocyst. Proc. Natl. Acad. Sci. USA 86: 3654-3658

Poelmann RE and Vermeij-Keers C (1976) Cell degeneration in the mouse embryo: a pre-requisite for normal development. In: Progress in Differentiation Research (N. Müller-Bérat, Ed.), North-Holland, Amsterdam. pp. 93-102

Prochiantz A and Théodoe L (1995) Nuclear/growth factors. BioEssays 17: $39-44$

Qureshi MA, Petitte JN, Laster SM and Dietert RR (1993) Avian macrophages: contribution to cellular microenvironment and changes in effector functions following activation. Poult. Sci. 72: 1280-1284

Reed JC (1994) Bcl-2 and the regulation of programmed cell death. J. Cell Biol. 124: $1-6$

Riese J, Zeller R and Dono R (1995) Nucleo-cytoplasmic translocation and secretion of fibroblast growth factor-2 during avian gastrulation. Mech. Dev. 49: 13-22
Rothstein JL, Johnson D, DeLoia JA, Skowronski J, Solter D and Knowles B (1992) Gene expression during preimplantation mouse development. Genes Dev. 6 : $1190-1201$

Ruoslahti E and Reed JC (1994) Anchorage dependence, integrins, and apoptosis. Cell $77: 477-478$

Sanders EJ (1986) Mesoderm migration in the early chick embryo. In: Developmental Biology, Vol. 2. Browder LW, ed. Plenum Publ. Corp., pp. 449-480

Sanders EJ and Wride MA (1995) Programmed cell death in development. Int. Rev. Cytol. 163: 105-173

Sanders EJ, Torkkeli PH and French AS (1996) Patterns of cell death during gastrulation in chick and mouse embryos. Anat. Embryol. (in press)

Santala P and Heino J (1991) Regulation of integrin-type cell adhesion receptors by cytokines. J. Biol. Chem. 266: 23505-23509

Saunders JW (1966) Death in embryonic systems. Science 154: 604-612

Schlüter G (1973) Ultrastructural observations on cell necrosis during formation of the neural tube in mouse embryos. Z. Anat. Entwicklungsgesch. 141: 251-264

Smith CA, Farrah T and Goodwin RG (1994) The TNF receptor superfamily of cellula and viral proteins: activation, costimulation, and death. Cell 76: 959-962

Snow MHL (1987) Cell death in embryonic development. In: Perspectives on Mammalian Cell Death, (CS Potten, ed.), Oxford University Press, Oxford. pp. $202-228$

Tabibzadeh S, Kong QF, Kapur S, Leffers H, Ridley A, Aktories Kand Celis JE (1995) TNF- $\alpha$ induces dyscohesion of epithelial cells. Association with disassembly of actin filaments. Endocrine 3: 549-556

Tartaglia LA and Goeddel DV (1992) Two TNF receptors. Immunol. Today. 13: 151 153

Tartaglia LA, Weber RF, Figari IS, Reynolds C, Palladino MA Jr and Goeddel DV (1991) The two different receptors for tumor necrosis factor mediate distinct cellular responses. Proc. Natl. Acad. Sci. USA 88: 9292 - 9296

Toné S, Tanaka S, Minatogawa Y and Kido R (1994) DNA fragmentation during the programmed cell death in the chick limb buds. Exp. Cell Res. 215: 234-236

Tracey KJ and Cerami A (1994) Tumor necrosis factor: a pleiotropic cytokine and therapeutic target. Ann. Rev. Med. 45: 491-503

Vandenabeele P, Declercq W, Vanhaesebroeck B, Grooten J and Fiers W (1995) Both TNF receptors are required for TNF-mediated induction of apoptosis in PC60 cells. J. Immunol. 154: 2904-2913

Vassalli P (1992) The pathophysiology of tumor necrosis factors. Ann. Rev. Immunol. 10: $411-452$

Vassalli P (1993) Knock-out but not knocked out. Curr. Biol. 3: 607-610

Wijsman JH, Jonker RR, Keizer R, van de Velde CJH, Cornelisse CJ and van Dierendonck JH (1993) A new method to detect apoptosis in paraffin sections, in situ end-labeling of fragmented DNA. J. Histochem. Cytochem. 41: 7-12

Wride MA and Sanders EJ (1993) Expression of tumor necrosis factor- $\alpha$ (TNF $\alpha$ )cross-reactive proteins during early chick embryo development. Dev. Dynam. 198: $225-239$

Wride MA and Sanders EJ (1995) Potential roles for tumor necrosis factor- $\alpha$ during embryonic development. Anat. Embryol. 191: 1-10

Wride MA, Lapchak PH and Sanders EJ (1994) Distribution of TNF $\alpha$-like proteins correlates with some regions of programmed cell death in the chick embryo. Int. J. Dev. Biol. 38: 673-682

Wright SC, Kumar P, Tam AW, Shen N, Varma M and Larrick JW (1992) Apoptosis and DNA fragmentation precede TNF-induced cytolysis in U937 cells. J. Cell. Biochem. 48: 344-355

Zhang S, Lillehoj HS and Ruff MD (1995) Chicken tumor necrosis-like factor. I. In vitro production by macrophages stimulates with Eimeria tenella or bacterial lipopolysaccharide. Poult. Sci. 74: 1304-1310 